\title{
Young Farmers' Perceptions of Sustainability in a Wine Region in Hungary
}

\author{
Adrienne Csizmady * (D), Bernadett Csurgó $\mathbb{1}$, Szabina Kerényi, András Balázs, Veronika Kocsis and \\ Botond Palaczki
}

Citation: Csizmady, A.; Csurgó, B.; Kerényi, S.; Balázs, A.; Kocsis, V.;

Palaczki, B. Young Farmers'

Perceptions of Sustainability in a Wine Region in Hungary. Land 2021, 10, 815. https://doi.org/10.3390/ land 10080815

Academic Editors: Bas Louman, Sara Scherr and Vincent Gitz

Received: 29 June 2021

Accepted: 28 July 2021

Published: 2 August 2021

Publisher's Note: MDPI stays neutral with regard to jurisdictional claims in published maps and institutional affiliations.

Copyright: (C) 2021 by the authors. Licensee MDPI, Basel, Switzerland. This article is an open access article distributed under the terms and conditions of the Creative Commons Attribution (CC BY) license (https:/ / creativecommons.org/licenses/by/ $4.0 /)$.
Institute of Sociology, Centre for Social Sciences, Hungarian Academy of Sciences Centre of Excellence, Eötvös Loránd Research Network, 1097 Budapest, Hungary; csurgo.bernadett@tk.hu (B.C.); kerenyi.szabina@tk.mta.hu (S.K.); balazs.andras@tk.mta.hu (A.B.); kocsis.veronika@tk.mta.hu (V.K.); palaczki.botond@tk.hu (B.P.)

* Correspondence: csizmady.adrienne@tk.hu

\begin{abstract}
Emerging evidence has shown that a sustainable mode of farming contributes to the sustainability of societies. However, agricultural modernization and land concentration have resulted in a decreasing role of agriculture in rural societies everywhere in Europe and also in Hungary. Governmental funds and agendas increasingly focus on the regeneration of rural areas with a special interest in the new generations of farmers. This paper analyses a small wine region in Hungary to explore the perceptions and activities of young farmers regarding sustainability. The paper is based on qualitative sociological research, including 20 semi-structured interviews with wine producers and other key actors of rural development in the region. The analysis focuses on generational change both in wine producer farms and in the wine region. How do farmers approach sustainability, and how does the concept of sustainability contribute to family wine production? How can generational change affect farming approaches and activities, especially changes toward a more sustainable way of farming? Our results show that rural regeneration can be understood not only as a generational renewal; it also includes endogenous development processes and new approaches targeting a more sustainable rural milieu.
\end{abstract}

Keywords: sustainability; generation change; young farmers; wine

\section{Introduction}

While the importance of agriculture as a labour market in rural areas has decreased in rural Hungary, the role of farmers in local societies is increasing. Land use is strongly diversified: many regions of Hungary are characterised by intensive land concentration and powerful landlords, while in some regions small farms are overrepresented [1]. Wine production has a special position in agriculture; the special geographical situation, including the soil, topography, climate, biodiversity, landscape in the vineyard, and identity of wine all indicate the unique position of wine regions in the rural landscape and society [2].

This paper analyses the case of the Mór wine region, which is one of the smallest but best-known wine regions in Hungary. Wine producers are important actors in local society: they are involved in many local activities, and they participate in local development planning processes, particularly focusing on tourism and local heritage development. Most locals have connections to wine and vineyards, so winemakers are seen as a kind of protector of local heritage and identity, as well as important actors within the local economy.

An intensive generational change has begun in the region in the last ten years, both within the family farms and through young farmers arriving in the region and establishing new businesses. The generational change includes more environmentally conscious attitudes, innovations, and the capacity of young farmers for a new, more sustainable approach. 
This paper seeks to understand farmers' approaches to sustainability and the possible effects of generational change on a more sustainable way of farming: how do farmers understand sustainability, and how do the different dimensions of sustainability change the farmers' attitudes towards winemaking? Related to these questions, we also aimed to analyse the role of generational changes within these perceptions.

A brief summary of the rural sociology literature concerning sustainability and farming, the role of sustainability in wine production and vineyards, and some aspects of generational changes will be presented in the first part of the paper. Then, the applied methods and two case studies on young farmers in the wine region will be presented. Different approaches towards the sustainability of young farmers will be analysed in the discussion section, and finally, we will conclude our paper.

\section{Theoretical Background}

Several issues arise in the context of sustainability in a wine region. The transition to sustainability perspectives has become a significant issue in the agro-food literature in recent decades [3]. Wine production and wine regions provide a particular context to understand the transitions and changes toward sustainability.

Before we summarise the main studies and approaches which link sustainability and vineyards together, we have to consider some issues related to generational change in farming, with a special focus on sustainability. First of all, sustainability in itself is an inherently intergenerational and also intragenerational issue in agriculture, as it entails a moral responsibility and a commitment over resources, with regard to the rights and needs of future generations, even though the costs and benefits are defined by the present users [4]. The goals of intragenerational equity can potentially conflict with the interests of the coming generations, as these goals have costs and more often than not involve restrictions of freedom and lifestyles [5]. Beyond approaching sustainability merely as a restriction or as a sacrifice, but also as a benevolent attitude based on morality, responsibility, or even the intergenerational "chain of love" (analogous to parental love) [6], we have been searching for further and broader approaches to sustainability in farming, as a diverse and dynamic operational concept.

We argue that sustainability includes several dimensions-we use the approach of the four pillars of sustainability [7] and confirm that sustainable development consists of four parallel pillars, namely ecological, economic, social and cultural. [8] Originally sustainability and sustainable development were rooted in ecological concerns, and the environmental dimension of sustainability was the most significant one. The social dimension of sustainability is strongly connected to institutional aspects of sustainable development, and the society and community aspects are also emphasised. Economic sustainability in relation to ecological dimensions is strongly connected to ecological modernisation, green economy, bio-economy, and organic farming. Ecological sustainability includes economic aspects with the combination of ecological and social goals. Cultural sustainability is a relatively new approach in sustainability discourse, which is strongly connected to the social dimension but also incorporates several new aspects such as heritage, cultural life, and local identity in the context of sustainable development [8].

In the last decade, we have witnessed a rising interest in sustainability in farming in general, as well as in the wine-making industry in particular. Among the numerous, sometimes vague definitions, it is important to point out that sustainability should not be mistaken for "organic" or "biodynamic" farming, as it involves ecological, economic, and equity principles as well [9]. The motivations for sustainability can vary too, and while there are many classifications, the most important division is that between internal (environmental consciousness, responsibility, quality of the products) and external drivers (consumer demands or other economic benefits). Research shows, however, that external drivers can diffuse into internal ones, which has helped sustainability become part of a "corporate image" in the most popular wine-producing regions (California, New Zealand), where sustainable wine-making has become quite profitable. As for Hungary, some recent 
studies suggest that "sustainability is an unknown term for consumers; not even experts or winemakers ... know exactly what it means" [10].

With a general trend of an expansion of farmers' markets and family farms [11], and also with an increased interest of young people in agriculture in Hungary, it is essential to discuss sustainability from the perspective of generational relations, too. Despite the importance of the topic, generational change and intergenerational farm transfer are relatively under-researched topics in rural sociology. Chiswell [12] analysed the transfer of managerial control of family farms, and she emphasises the role of individualisation processes in intergenerational transfer. Many scholars [13-15] confirm that rural regeneration and especially intergenerational transfer in family farming is crucial to the continuity and future of family farms and also of rural society. Studies prove that the younger generation seeks and demands greater independence and autonomy, and if this is not possible, the succession can fail. Conway et al. [13] highlight that understanding the new farming habitus is crucial in order to appreciate all aspects of succession in farming communities. Habitus is also emphasised in the context of organic farming. Sutherland and Darnhofer [16] state that organic farm conversion and the connected good farmer symbol include several cultural aspects which contribute to the changing habitus of farmers and a changing understanding of what constitutes good farming.

Social, cultural, and emotional aspects of intergenerational farm transfer also appear in the literature $[13,17,18]$. Conway et al. [17] prove that farmer-farm attachment is a focal point to understand generational change in farmer society. Psychodynamic and sociodynamic factors influence the farm transfer between generations, and the emotional attachment to the farm and place strongly determine the success of intergenerational transfer. Both the attachment of old and young generations are important factors. The so-called 'soft issues,' that is, the emotional and cultural issues, significantly influence the future trajectories of the farms.

Vineyard and wine production constitute a unique example of both generational and sustainable changes. The vineyard in itself is a special landscape with very strong cultural and attractive natural characteristics $[3,19]$. Wine identity and local identity are interconnected. A study of identity markers of wine producers in France, Spain, and Australia emphasises the importance of self-identity, which can include AOC, terroir, organic farming, and other elements, which go beyond market interests: "differentiation strategies are not chosen merely because of their market potential, but must align with the identity construction of the owner/winemaker as an artisan wine producer" [20].

The case of a Sierra Nevada vineyard [21] demonstrates that wine growing and wine making as a cultural phenomenon have a significant impact on identity and place making. "The pursuit and construction of the Sierra Nevada foothills as 'wine country' becomes a means through which the place 'makes' itself and, in turn, makes a place for itself across a variety of economic and cultural contexts" [21]. The case of Chile [2], where sustainable farming practices and biodiversity protection are very rare, shows that sustainable farming practices have significant cultural impacts. Wine producers involved in a sustainable farming program recognised the cultural benefits of nature during their participation in the program and also emphasised the organisational and community influences of the programs. The case of organic wine production in Panzano [22] represents a case of rapid and successful sustainable development in a wine region, and also confirms the sense of place and local identity, which facilitates the cooperation of local stakeholders and knowledge transfer. The importance of knowledge, including local knowledge [23], is also demonstrated by the case of Namea in Greece, where the wine as a local product has a significant role in territorial development [23]. However, the case of Santorini, where market forces influenced landscape change much more than policy initiatives did, shows that cultural impacts of sustainability interventions, including agri-environmental approaches, are hindered by the intensive growth of wine and tourism markets [3]. Other important aspects of wine markets are presented by the case study of a Sicilian wine cooperative. The case of the Cantina Cellaro wine cooperative in Sicily [24] shows the 
importance of the restructuring of wine cooperative systems, and particularly, how the new form of integration of economic actors contributes to the economic success of the wine cooperatives, including the capacity to respond to increasing competitive pressure and to the ever-greater diversification of consumers' demands and preferences [24].

With the wine industry being tightly connected to tourism, particularly in small wine regions, which build on a strong local identity, it is essential to emphasise that ecotourism is rising worldwide in historic, large wine areas (such as Chile and California), and it is meeting a general demand by consumers for "sustainable tourism" or "alternative tourism" [25]. A case study from a Western Sardinian wine region [26] demonstrates the importance of tourism as an economic tool for farm development and also shows how value creation and multifunctionality can increase farm incomes and meet consumers' demands. At the first wine conference of the UN World Tourism Organization in 2016, an explicit declaration was made on wine tourism, emphasising the importance of sustainable development and sustainable tourism, "cultural and natural resource preservation," the inclusion of underdeveloped rural areas, as well as the promotion of local cultures and lifestyles [27].

At the same time, similar phenomena have been described in the literature on Southern and Eastern Europe. While the contribution of tourism, and in particular, sustainable tourism to local economies is less significant, it can contribute to the improvement of opportunities and quality of life for locals, and can provide a "higher local attractiveness for new residents" [26,28]. With our field research, we seek to examine the possibilities of sustainability in a micro-region, where the rate of family farms ranks above the national average. At the same time, we also discuss the inter-generational aspects of sustainability in a generally aging area, where nevertheless, new trends of a growing young population have emerged, and the outmigration is below the national average.

\section{Materials and Methods}

\subsection{Data and Methods}

Our case study focuses on the farming approaches of the new generation of farmers. We identified two types: successors and newcomers. The case study research focused on farming methods, attitudes, and perceptions about sustainability (including ecological, economic, social, and cultural), innovation capacity, and attachment to place, local identity, and future visions. We conducted 20 semi-structured interviews with locals: 15 with farmers and 5 with local key actors (local government, tourism, civic associations) and 1 focus group with stakeholders, including farmers. The interviews and the focus group took place in March-April 2021 and were conducted online because of the COVID-19 pandemic. All interviews and the focus group discussion were recorded and transcribed.

We initially divided the interviewees into two groups according to their main characteristics and particularly their attachment to the place, separating "newcomers" (8 interviews) from winemaking "successors" (7 interviews). An additional, third group was formed by other key actors related to the field of wine production, consisting primarily of mayors and figures from the catering industry (with hobby wine producers among them) (5 interviews).

While we received some key points and gained important supporting arguments from the interviews with the other key actors, in this paper we present the analysis of interviews of farmers (both newcomers and successors). We have analysed the narratives of farmers through the following aspects:

- Description of the vineyard (origin, motivation, work in the farm, etc.)

- Attitudes toward sustainability (environmental, economic, cultural, and social issues). As we mentioned above, we use the approach of the four pillars of sustainability [7].

- Innovation, resilience, new trends, and consumers' demands

We have summarised our case study analysis in the context of generational change. The limitations of qualitative research, such as the lack of external validity, can be a risk in this analysis; however, the case study may provide a deeper insight into young farmers' 
perceptions on sustainability in a particular area and may confirm the benefit of the four pillar approach to sustainability in a wine region context.

With the focus group, we aimed at achieving an insight into the dynamics of the relationship among the farmers themselves, as well as between the farmers and other key actors who work in and for the development of the region. We focused on common problems of the region and the winemaking and tourism industry itself, on the vulnerability of producers in a small wine-region, as well as joint interests and potentials in the region, and possibilities of self-representation on the market. During the focus groups, different aspects of sustainability also came up.

In order to understand better the Hungarian and local context of agriculture and viticulture, we use the official statistical data of the Hungarian Statistical Office (HSO 2010, 2020). Unfortunately, the agricultural census is only available every 10 years, and at the national level only some preliminary data from the 2020 census are available, therefore these are not detailed enough to give a more precise overview. With the statistical analyses, we wanted to understand and illustrate some general trends of the industry and its place within the country, as well as to better describe the region we have studied.

\subsection{Study Area-The Agricultural Context of Hungary and Mór Wine Region}

The number of farms has steadily declined since the regime change. Between 2010 and 2020 , the number of farms decreased by more than $40 \%$, and in 2020 , there were 234,000 farms in Hungary. The proportion of farms predominantly involved in animal husbandry is steadily decreasing. Compared to 2010 , their share has decreased from $46 \%$ to $25 \%$, while the share of those that are mainly active in crop production has increased by almost the same amount. In 2020, most of the more than 4.8 million hectares of agricultural land $(82 \%)$ was arable land, and only a very small proportion (1.3\%) was for grapes. Half of the utilised agricultural area was leased, and only $45 \%$ was owned by farms. At the same time, the proportion of farmers under the age of 65 fell from $72 \%$ to $65 \%$ between 2010 and 2020, but the average age of farm managers increased. Generational change has not yet begun: in 2020, the proportion of farm managers under 40 was 3\% lower (10\%) than in $2010(13 \%)$. Another addition to that is that a large proportion of older farmer managers work without a degree but with practical experience. Concerning the age distribution of the winemakers, $11 \%$ are managers aged $14-39,64 \%$ are $40-64$ years old, and $25 \%$ are managers aged 65 and over. Among the younger farmer managers, the proportion of those with specialist training is already higher ( $14-39$ years: $60 \%$; $40-65$ years: $42 \%$; over 65 years: $28 \%$ ). More than half of the managers $(54.9 \%)$ have not yet thought about the generational change yet, or do not know to whom they will hand over the management of the farm. Farmers who are already planning to hand over the business in the future are planning to do so mostly within the family. Precision farming tools are used by only $1.5-5 \%$ of farmers, most of whom do not think they are needed during production.

\subsubsection{Viticulture}

Hungary is one of the smallest wine-producing countries, with a total vineyard area of 58,000 hectares. In the last ten years, annual wine production averaged 2,667,000 hectolitres. However, compared to 2010, the area per farm has increased in all cultivation branches and more than doubled for grapes (2010: 0.8 ha; 2020: 1.8 ha). While $72.7 \%$ of farmers work in their own fields, $20.4 \%$ rent them, with an average size for leased land of 10 ha. The proportion of self-owned areas increases as the age of farmers increases.

As in other countries within the European wine industry, there are specialised trading companies, social cooperatives, and family wine cellars (with winemaking in connection with the farm). In Hungary, the proportion of small family businesses is very high, and they try to revive and preserve traditional lay knowledge alongside innovative methods in viticulture. This shows in the size of the farms $-72 \%$ of the vineyards cultivate only between 5 and 299 hectares. The share of the smaller companies is $23.4 \%$, that of the larger 
ones $4.7 \%$, while the share of the area used by young farmers is highest in fruit growing and lowest in viticulture

Organic farming has significantly more administrative burdens than ecological farming, and at the same time, it is also more expensive. In Hungary, two EU funding sources are available for wineries, but farms can only receive support from one. Obtaining the so-called Agri-Environmental Support (AES) is easier, as it requires a simpler administrative process. To obtain the alternative organic support, more administration is required, and the renewal of the organic label involves not only review but also an annual financial investment. Farmers very often choose the former not only because of the simplicity, lack of review process, and lower investment required, but also because the acquisition of organic certification is hampered by the regulatory and support environment.

\subsubsection{The Wine Region}

The Mór wine region is one of the smallest of Hungary's 22 historical wine regions. It is located in the north-western part of Hungary in the northern part of Fejér County. The region is a predominantly rural area, with villages and small towns belonging to the Mór microregion (Figure 1). The area is relatively well located and accessible, lying close to the cities of Székesfehérvár (about $30 \mathrm{~km}$ ) and Győr (about $60 \mathrm{~km}$ ), and about an hour's drive from the capital Budapest (about $60-80 \mathrm{~km}$ ). Due to the proximity of the region's settlements to these big cities, the villages have become a very popular place to live over the past 20 years, and the population of the settlements has increased.

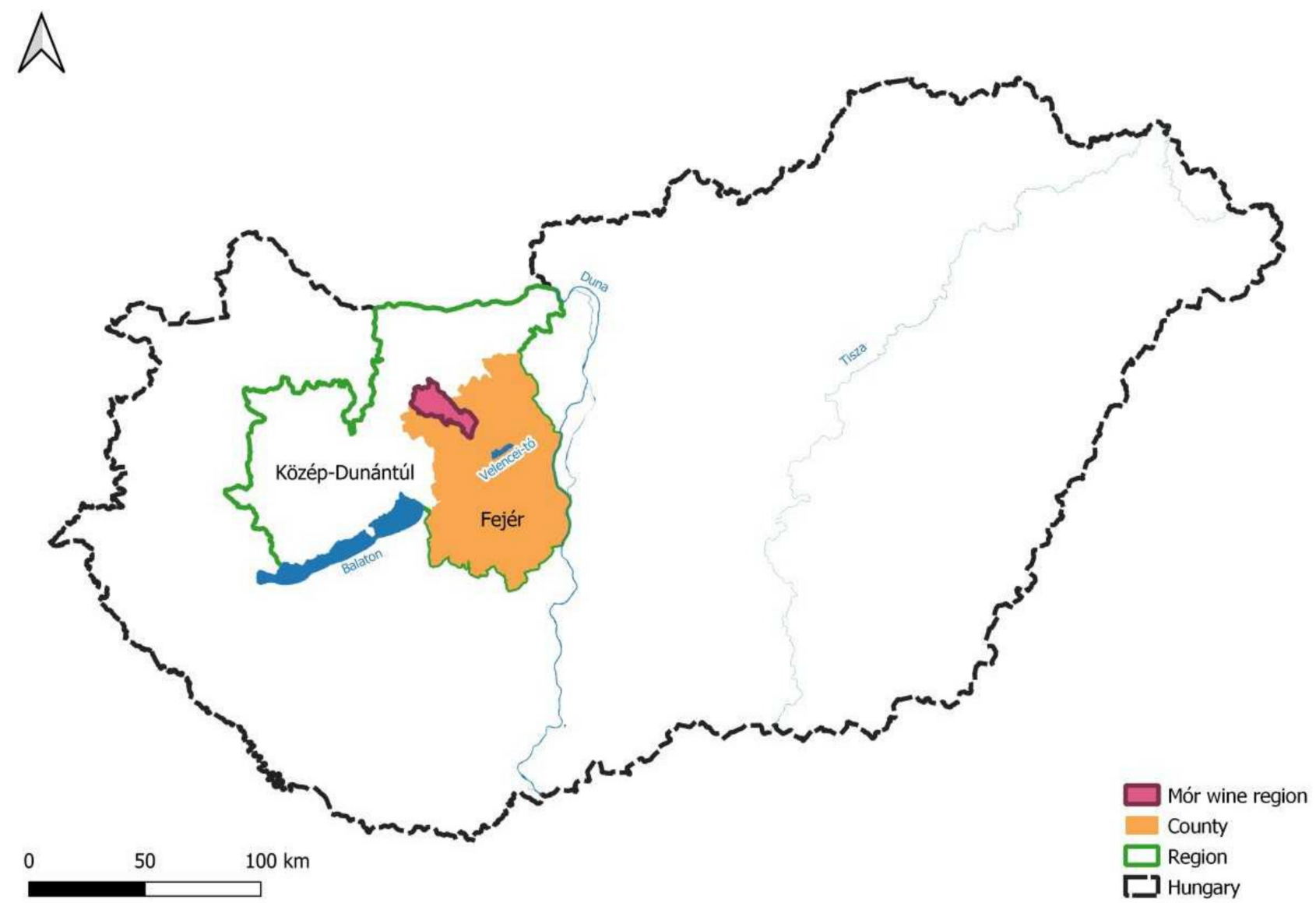

Figure 1. The study area of Fejér County.

The Mór wine region contains six settlements: Mór, Pusztavám, Söréd, Csókakő, Zámoly, and Csákberény. There is a difference in size between the settlements, with the smallest, Söréd, being $6 \mathrm{~km}^{2}$ in area and having 555 inhabitants, while the largest is the 
district town, Mór, which has 14,000 inhabitants and covers an area greater than $100 \mathrm{~km}^{2}$. In contrast to Csókakő and Mór, which are more densely populated than the national average, the population density of Zámoly and Csákberény is 30-50 inhabitants $/ \mathrm{km}^{2}$. Half of the Mór wine region's area is under Natura 2000 protection.

The wines of the region are typical white wines. The traditional grape variety of the region is the Ezerjo (thousand boon). The Ezerjó belongs to the Hungaricums, and the wine region is famous for it.

The Mór wine community was founded in 1995, shortly after the regime change in 1990. At that time, a lot of small wine farms were founded here as part of the privatisation of former cooperatives, when local farmers in particular bought the land and ran small wineries. Under socialism, the Mór State Cooperative was responsible for viticulture, storage, and a significant part of sales. Today, the community cultivates 600 hectares of vineyards, and has 82 members in six municipalities, and around 60 winery firms (including family businesses), and many hobby farms work here.

The active production area grew by $42 \%$ from 2011 as a result of active grape planting financed by EU supports in the last decades. However, the area planted with grapes has decreased by $32 \%$ in the last ten years, which means that the production area will not grow significantly in the future. Today the vineyard area is 492 hectares, which is $0.78 \%$ of all Hungarian vineyards, and $10 \%$ of grape varieties are planted.

The Mór wine region, traditionally the smallest in the country, witnessed the largest increase by production area in the country during the mid-2010s, surpassing the NagySomló wine region for 5 years. As a result, the harvested quantity was exceptional in the years 2017-2018, reaching and surpassing 30,000 quintals. The wine region of Mór is almost exclusively specialised in producing white wine: $94 \%$ of the grape-growing area is devoted to white grapes, which is much higher than the national average $(70 \%)$.

Most of the wineries we have studied are small or micro-sized, and they are mostly run as small family business. Most of them sell their products in small local markets or at the vineyards; however, many of them have entered the top gastronomic networks, producing and selling their products for elite consumers such as fine dining restaurants.

In almost every settlement in the Mór microregion there are harvest days, village days, and other festivals. Most of the events in the micro-region relate to the autumn harvest. The largest events, attracting thousands of tourists, are the Mór Wine Days, the St. George's Days, and the Csókakő Castle Games.

The main goals of the Wine Community are to create a strong network between the wine producers and related actors such as tourism and cultural organisations in the region. They also aim to help the farmers (successors) to continue running the family businesses, and at the same time to help newcomers to integrate in the area. The community also organises and supports events that are based on the preservation of local heritage in the area.

\section{Results}

\subsection{Case Studies}

We have identified two types of young farmers in the region: successors who continue the family business and newcomers who started new farm activities in the region. In the following, the main characteristics of these two types of winemakers will be presented. The case studies describe the main aspects of generational change including innovation, network, and attitudes toward sustainability.

\subsubsection{Successors}

The first case study focuses on the successors, the new generation of farmers who have always lived in the region, have worked or participated in the family business since childhood, and have either taken over or will possibly take over the management in the near future. 
Most families have had a long experience in winemaking, and were already involved in viticulture before the regime change in 1990. During state socialism, wine was produced in state-owned co-operatives in the country. In addition to that, almost all farmers had small vineyards as a hobby garden, where they produced wine on a small scale mainly for home consumption. This attachment to the vineyard and winemaking was an important basis for starting a family business after the land privatisation.

"In 'Szentbékkálla' there was also a small family cellar, which was managed on an area of a few tenths of a hectare. They could make some extra income out of it. My other grandfather worked in the mine, but they also had a small piece of a vineyard ever since I can remember... It meant a lot to them."

After the regime change, the state viticulture was privatised. Several families saw a market opportunity and bought a wine-growing plot to expand their small business.

"It was a thriving industry in the mid to the late 1990s and early 2000s. It went very well. Wine consumption per capita was relatively high in Hungary. State-owned companies became practically non-existent by the mid-1990s. The markets were taken over by private companies. It was obviously a promising sector, there seemed to be a rationale in this story."

Based on their previous experiences, some of which go back several generations, they began to work as a family farm business, mostly with the involvement of their relatives. A typical farm size today is still small: the grapes are grown on the surrounding areas, which are approximately 5-25 hectares in size.

"The three generations look as follows: the grandparents, during socialist times, from the 1950s to the 1990s, were involved in viticulture in small-scale home farms at the Balaton. My grandfather on my father's side learned winemaking at a crash-course, and worked at the winery in the socialist cooperative in Zánka. (...) And my father also chose wine-making for a vocation. (...) He graduated as a winemaker technician in 'Budafok' and worked at the 'Badacsony Winery', then later at another company and then finally for 'Mór'. This is how the family moved to Mór."

The vast majority of our interviewees joined the family businesses as second-generation winemakers with appropriate professional training. Although their ambitions came from the family, they deliberately developed the businesses independently. They are the successors.

"The motivation really came from the family. I received impulses, so to speak, and as a child I enjoyed going to the vineyard. (... ) My family encouraged me, and I never regretted that I started this profession, which I later continued throughout my university studies. I saw an opportunity in it."

The emergence of the younger generation is already widely apparent.

"The young people between 30 and 50 are already present in almost all wineries. We can say that we have completed almost an entire generation change."

The new generation obviously wants something different from the previous generations. They are also more sensitive towards the effects of globalisation and climate change. New methods and new techniques have inevitably started to appear on the farms as a result of this generation change. The successors have the capacity and interest to apply for funds such as agro-environmental support (AES) or to learn new methods and approaches, whether in farming or other related activities such as marketing and tourism.

"Well, I now see such a rejuvenation in the winery. The generation change is going smoothly: in each family they can find the appropriate person who takes over this winery. And that will certainly bring on further development, because the young people will no longer appreciate and be satisfied by everything that was done by their ancestors. This will bring forth a positive change in the quality." 
New farming approaches and innovation both in farming and marketing are significantly emphasised by young farmers. The labour force demands of the studied farms are mostly based on the full-time employment of family members, and on seasonal employment of agricultural workers from the neighbouring settlements.

Most of the wineries practice traditional farming, but they strive to minimise their environmental impact (limiting the use of chemicals), and some are experimenting with the use of solar energy. Wineries have limited resources for development, so they have to use alternative solutions to maintain ecological and economic sustainability. According to interviewees, the solution is to reduce the cultivation area in parallel with mechanisation. Mechanisation is emphasised both in the context of the reduction of labour-force demand and finding environmentally friendly methods.

"We are applying environmentally conscious plant protection, which means that we use environmentally friendly plant protection products, and we do mechanical weed control in a more environmentally friendly way which does not destroy the soil and the wine. We only cut the weeds in the rows and we supplement the nutrients with organic manure."

In addition to supplying a wide range of consumers, an increasing range of quality wine and wine tourism is inevitable.

"Well, where do we sell in practice? We are practically everywhere from grapes to hospitality. So we sell quite a lot of grapes as fruit, we sell cider, we sell wine in bottles, we sell wine in plastic bottles, we sell bottled wine. And we also sell wine for hospitality. From this point of view, everything is included, from the grapes to wine tasting."

Marketing is a crucial aspect of the success of wineries. Young farmers focus more on marketing issues than older ones. Although they develop their marketing activities, their reputation is initially spread by word of mouth even today. Small wineries of the region still serve local and neighbouring needs.

"Our main profile in the past few years was the supply of pubs, where we delivered bulk wine. This is the pub segment, it is quite a narrow segment, so since then we have tried to open up to hospitality, restaurants, shops, and businesses."

They have to be diverse and present in a wide variety of markets in order to be able to sell their products, and so that the family can make a living from the family business.

"We don't deliver to multinationals, it's not a route for the size of our company. On the other hand, the share of sales from the house is quite high, so that locals or local buyers in particular should have it as lower-quality poured bulk wine or bottled wine. So now I can say that all in all this is very chaotic; many areas have very, very many segments."

Several interviewees emphasised that the change of consumers resulted in improvement of wine quality, with some aspects of sustainability. Wine became part of local tourism and local products. Visitors and consumers have started to demand explicitly local gastronomic products, including food and wine.

In recent years, a number of NGOs, including the local Tourism Destination Management Association, have been set up to bring together families who are involved in viticulture. They are building a strong network to make the area better known for its hospitality and wine and are involved in organising local wine festivals, for example. Some of the interviewees play important roles at the Wine Community, and they try to unite the new generation who regard quality development as a matter of prestige.

"A new generation has emerged who are already interested in quality wine production.

They already know that the name and reputation of the wine region matters in sales as well. (...) As for local events, we can see a unity among almost all winemakers. So, here we have a common goal that everyone can benefit from."

The local development policy of the settlements also focuses on local characteristics, and is increasingly building on the elements of local culture as a resource. Local authoritiesin cooperation with local companies-aim to make the wine region a popular wine tourism 
destination with services for the whole year and not just a single event destination, such as the traditional spring and autumn festivals.

\subsubsection{Newcomers}

The second type of young farmers that we have identified are the newcomers, farmers who have not previously worked in agriculture and did not previously live in the area of the case study, or often not even in rural areas. Their families were never involved in farming nor in viticulture, and they do not have any previous knowledge of viticulture.

"There was nobody in the family [who had experience with agriculture], we were a classic middle-class family, nobody cared about it, we didn't go anywhere near the country."

The studied newcomer winemakers have different educational backgrounds (e.g., economics, mechanical engineering) before they started their wine business and moved to the region. However, they established relationships with viticulture during their university studies (e.g., during internships). Some of them even spent time in this wine region too.

"( ... ) then I decided that I wanted to learn more about wines because I found it amazing!"

All of the interviewees emphasise how they started to be interested in wine production. The interest went beyond a hobby, they learned more and more about wines and the associated technologies, and some of them attended courses and training at different educational levels, or even enrolled in a university programme.

"And afterwards something changed completely and I put all my time and money into this training."

Apart from a few internship semesters or wine tastings in the local wineries, they had no personal connection to the region. They decided in favour of this wine region above all because the location has good natural potential in agriculture and viticulture, and the wine region is centrally located and easy to reach. The beauty of the landscape and the rural idyll were also motivating factors for the newcomers to start their practice there.

"I liked the landscape when I first got on Route $81 \ldots$ and I still remember how I felt when I saw the 'Csókako"' hill, the castle. ( . . . ) Even today, I feel what I felt when I first saw this landscape. (... ) Lord, that's beautiful!"

Initially, they decided to lease a cellar and commuted between their city apartment (mainly in Budapest or in other nearby cities) and the cellar. After a few years, some of them bought a cellar and moved to the settlement. They started farming in small vineyards, but in recent years the vineyards have expanded, and the previously leased land could be bought, mostly with EU support. Today, most or all of the land belongs to them. Compared to other vineyards, newcomers cultivate smaller areas of 3-4 hectares.

"( ... ) Just a small territory belonged to the cellar, $3000 \mathrm{~m}^{2}$. We are not that big today either. So we have 3.5 hectares."

The farms are family businesses and only 1-2 people work in the wineries who are not family members or friends, which is partly due to a concern regarding the general shortage of seasonal workers. Some of the new wineries try to involve the local younger generations to make them familiar with viticulture. They established a school garden and a model farm where they show the local youth how the winery and viticulture work until harvest.

"There are now two young people (... ) who pruned the grapes here twice in November and January and they said that they were interested (... ) in accompanying the whole process. That's all we can offer now, so if someone is interested, we will show them how it works. Then we can recommend them to get a series of grapes that they can cultivate, harvest, spray, and make wine out of them all year round."

There is a concept of expanding the vineyards and expanding the cellar in the future, but not on a large scale. To expand the gastronomy, larger rooms for guests for wine 
tastings or guest houses are planned. Some of them want to expand the territory through concerts and performances, which can bring the community closer together and increase the customer base.

"It's such an outdoor garden, in the middle of our vineyard. We want to develop these where a concert, even a small theatre performance or a reading evening could take place. So it would have a bit of community-building power."

Maintaining innovation and local traditions is important to the newcomers. This duality is also evident in the wineries, where they try to combine innovation with tradition: innovation in organic farming and viticulture, and maintaining more environmentally friendly mechanised agriculture, which becomes even more necessary due to labour shortages.

Newcomers brought a new perspective on local viticulture with the start of ecologically sustainable cultivation in the wine region. The shift to fully organic farming is on the way: lately, they have not been using any chemicals, just the natural ones that are approved for organic farming, and some of the wineries only produce organic wine. This is only a slowly emerging tendency though, and only a few farmers have adopted this approach because, as noted above, this type of farming is more expensive and imposes extra bureaucratic burdens compared to the conventional one.

"It has to be innovative in something, especially in terms of sustainability and cultivation in the vineyard. Of course, we also strive for organic farming, the region is lagging behind. There are some farms that think that way; I trust that more farmers will think that way."

The winemakers have played a significant role in marketing the wine region, and the newcomers have brought innovation and more new ideas. They have linked wine consumption to local natural values and used it as a marketing tool to attract more visitors.

"Actually, the goal is to make quality wine and promote the landscape."

All newcomers cultivate the so-called brand grape of the region. This helps to maintain tradition, and at the same time it makes the cellar and the region more popular with tourists. The newcomers take an active part at the local and national wine festivals and competitions, which is a good marketing tool and strengthens the local identity too.

Newcomers may not have local roots, but they strive to build a well-functioning local network. They care about local values and traditions and fully identify with them, despite having no personal connection prior to starting their work.

\subsection{The Perceptions of Sustainability}

We have applied a four pillar approach to sustainability during the analysis - we have collected information on how the interviewees talk about environmental sustainability, focusing on the narratives about farming methods and plant and landscape protection. We have also looked through the narratives about cultural sustainability: how the farmers themselves talk about local traditions, heritage, local image, and identity, including identity related to winemaking. In the context of social sustainability, we gathered narratives on local community, local networks, demographic changes, and the labour market. Finally, in the context of economic sustainability, we focused on the narratives about how environmental issues intersect with economic success on two levels-both the family farms and the region.

The case of successors shows that the transfer between generations of managerial positions can result in some conflicts. Nevertheless, it also has some clear benefits to the business of winemaking, too: new ideas, innovative capacity, and also the new approach of young farmers are the crucial aspects of generational change. Young farmers are open to new marketing strategies and they participate in new local and non-local networks. It is important to emphasise that even if they intend many changes in farming methods, they have a very strong local identity, their attachment to the place is very strong, and 
local traditions and heritage are strongly emphasised in their narratives. They talk about sustainability mostly in the context of the cultural heritage of the region, while wine and wine production are part of the local heritage and identity. They are very active in the protection of this heritage including the characteristics of the landscape. Ecological sustainability is strongly connected to the natural heritage of the region in their point of view, and they experience it as a kind of consumer demand.

Newcomers have a very different motivation for farming. They emphasise the creativity in winemaking, and they romanticise the "back to the land" approach, where the idyllic landscape serves as an additional source of motivation for farming and for moving to a rural area. They emphasise the positive geographical location of the region: the proximity of Budapest and other big cities were important factors in their choice. Climate change and ecological sustainability are strongly emphasised in their narratives, as they create a link between traditional and organic farming approaches. The wine identity and the related local traditions are very important for them; moreover, they regard the traditional methods and farming approach as innovative, "new", more ecologically friendly, especially in comparison with conventional, industrialised farming. However, they also use innovative marketing strategies and try to find new channels of work opportunities, for example, by making the harvest a recreation activity or community-building event. They highlight the importance of involving young locals in the wine traditions and teaching them tacit knowledge about viniculture. The ageing of the labour force and the lack of young agricultural workers are strongly emphasised in their narratives too. Newcomers initiate new networks and new farming approaches in the region.

Table 1 shows the perceptions and different dimensions of sustainability for the two types of farmers.

Table 1. Perceptions and different dimensions of sustainability for the two types of farmers.

\begin{tabular}{|c|c|c|}
\hline Dimensions & Successors & Newcomers \\
\hline Ecological & increasing consumer demand & $\begin{array}{l}\text { risk of climate change, } \\
\text { environmentally conscious } \\
\text { behaviours, organic farming } \\
\text { approaches }\end{array}$ \\
\hline Economic & $\begin{array}{l}\text { diversification of local economy } \\
\text { including sustainable farming }\end{array}$ & $\begin{array}{l}\text { environmentally friendly local } \\
\text { economy }\end{array}$ \\
\hline Social & $\begin{array}{l}\text { decreasing size of workforce, ageing } \\
\text { of agricultural workers, inclusion of } \\
\text { younger generation }\end{array}$ & $\begin{array}{l}\text { decreasing size of workforce, } \\
\text { ageing of agricultural } \\
\text { workers, involvement of new } \\
\text { social groups (visitors) in } \\
\text { agricultural work }\end{array}$ \\
\hline Cultural & $\begin{array}{l}\text { local heritage, landscape, traditions, } \\
\text { local identity }\end{array}$ & $\begin{array}{l}\text { wine identity, local identity, } \\
\text { place attachment }\end{array}$ \\
\hline
\end{tabular}

Source: Authors' own compilation.

Several aspects of sustainability appear in the narratives of farmers. Cultural sustainability is the most emphasised by successors, while newcomers focus more on ecological sustainability. However, we can say that both types of young farmers are motivated toward more sustainable farming. Multiple motivations toward a more sustainable farming approach appear in their narratives. Climate change is strongly emphasised by newcomers, while successors perceive sustainability as a kind of consumer demand. Both groups of farmers regard traditional farming as a more sustainable way of farming.

Generational change both in family farms and in the region results in and supports a more environmentally sensitive attitude of farmers and may lead to a more sustainable farming approach.

\section{Discussion}

In this section, we would like to discuss the findings of the case studies, reflecting on the original question: how do the different types of farming relate to sustainability, and 
what approaches to sustainability do these groups have? As we have presented through our case studies, the two identified types of farmers experience and approach sustainability very differently.

The case studies have shown that various dimensions of sustainability are becoming increasingly important in the Mór wine region. Most wineries work as traditional family farms, and only a few strive to have the least possible environmental impact. The case study analysis confirms previous research findings [16,29], showing that farmers in the studied region also emphasise that organic farming is expensive and complicated, and that obtaining the organic farming title requires a lot of administrative effort.

The subsidies for organic farming in recent years have increased in Hungary, too, and the number of organic farmers has doubled in the period between 2015 and 2019. Nevertheless, Hungary is still lagging behind compared to the EU average (ranking 21st in the size of such farms), and the subjective narratives are also centred around the difficulties and disadvantages of organic farming [30]. The process of obtaining the ecological certification is often lengthy and expensive-both financially and administratively. The certification requires, among other things, a change of the nutrient replenishment, and a complete transfer from pest control to biological control, which can involve higher risks. For local, sometimes more vulnerable plants (such as local types of grapes), there is less knowledge available for the farmers, and the knowledge transfer is often lacking. For small, family-run farms, this risk often exceeds their capacities; moreover, it is not even justified by a market demand either, as consumers would typically search for local products, but not necessarily certified ecological wines.

Organic farming represents only one aspect of sustainability in the wine industry and, as our study shows, it is possibly the least dominant one [2,3]. As we found out in our research, the studied farms only meet the criteria of organic farms in a few respects. Organic approaches are, however, being brought in by newcomers and young farmers from the successor group to a greater extent. Nevertheless, the collaboration between young and older farmers, within the context of generational change, can catalyse a successful change towards both ecological sustainability and quality production. Even if small family farms are moving towards mechanisation, they are still struggling with persistent labour shortages because young people are not drawn to hard agricultural work. These farming methods, including mechanisation, can be various, and tend to include environmentally friendly aspects as well. Thus, the methods themselves do not necessarily contradict the principles of sustainability.

Moreover, the consumer demands are more explicitly pushing for local goods, but they also demand ecological qualities. This case study confirms the previous results of case studies from different wine regions, which show the importance of changing consumer demands in the development and restructuring of wine regions. Nevertheless, the restructuring toward ecological sustainability in the Mór wine region is slower than, for example, what was shown by the case of Panzano in Italy [22], even if the role of local identity is similar. The producers in the Mór wine region prefer to opt for "hybrid" methods, which means that the use of environmentally harmful agents is minimized. For all these reasons, applying for the title of organic farm is not a priority for the farmers.

There is a generational change in the long-standing family wineries, and there is also an increasing number of newcomers to winemaking. While the new generation typically promotes ecological sustainability, the newcomers came to the wine region with no previous connections, and often link innovation to the preservation of local traditions. However, our analysis also shows that there is a significant difference in the perception of sustainability between successors and newcomers. For successors, sustainability is a kind of market-driven phenomenon, while for newcomers it is more 'ideologically driven', with a stronger connection to ecological issues. Both newcomers and locals, and especially the young generation, have a very strong local identity. It is important to them to preserve local traditions and promote local wine, and to participate in local events and festivals. They have also made it their business to train young people. On the one hand, it serves 
the marketing of wines, and on the other hand, it helps create a new generation of farmers and more environmentally conscious consumers. They think long-term and, in addition to winemaking, are also committed to hospitality in order to make the winery more economically successful. The successors follow international and national trends and, being aware of changes toward sustainability, they are ready to apply the latest methods and innovations. Conflicts often arise between successors and parents who prefer more conventional methods.

Young farmers in the Mór wine region have a strong perception of the importance of cultural sustainability for the wine industry. The cultural identity of the territory is identified by and interrelated to the quality characteristic of the local wine. We have found that for a small and relatively peripheral wine region, cultural perceptions of sustainability are much stronger than the ecological dimensions, compared to large and historical winemaking regions. First of all, culture contributes to the formation of place and identity of the wine region and the producers, and as such, it determines the relationships between the generations, even if it does so differently for the two studied groups, newcomers and successors. Secondly, ecological sustainability, and the perceptions of ecology in farming, show a rising tendency, but are still less attractive and involve additional burdens for the farmers, therefore the trends are less visible than they are in historical, traditional wine regions in core countries of the EU.

As ecological sustainability is costly (both financially and administratively) and the market demands for ecological sustainability are not too explicit, maintaining sustainability could rely mainly on cultural and social pillars. At the same time, there is a strong interaction between tourism, hospitality, and wine. The change is triggered by the changed consumer needs, mainly of the middle class. Therefore, the area is moving towards consumer-generated sustainability and this involves a generation change, which is also associated with technical innovations. The motivation to work in agriculture is generally decreasing, and farmers are trying to make up for the labour shortage through mechanisation and the use of innovative methods. However, the relationship between tradition, sustainability, and innovation needs further analysis. Maintaining local identity and local networks plays a key role and is closely related to economic success and social sustainability. The local cultural and economic network between farmers and other entrepreneurs in the field of tourism compensates for the vulnerability of family businesses. Together they are better able to survive and together they also contribute to the development of the image of the place, which has an impact as an important factor for sustainability.

In parallel with the increasing number of tourists in the region and the growing demand for local food, farmers have changed their target consumer groups. Local markets and local inhabitants are not the main consumers of their products anymore, and the farmers now offer their wines through various supply channels, from online shops to the small wine shops providing higher-quality wines for mostly urban consumers. The importance of on-site selling for tourists parallel with the tourism development of the region is expected to increase in the future. The market for cheaper wines has shrunk significantly, while the demand for quality wines is increasing [3,24]. On the other hand, manufacturers react to changing needs and the increasing demand for local products are motivating factors to achieve higher quality. The latest marketing platforms, in turn, are connecting the economy more closely with consumers with changing demands [27].

Following global trends, consumer demand has recently shifted significantly in favour of small wineries in Hungary, too, as this case study has confirmed. The new trends and consumer demands include preservation of local values, the preference for products of family businesses, and the enjoyment of special, local, and high-quality wine [9,25-27]. The newly emerging forms of rural tourism and new and more intensive rural-urban relationships can positively affect the farm businesses in the region, which may contribute to the capacity of the region to retain its population. The emphasis on cultural sustainability is also growing at the local level. 


\section{Conclusions}

In our paper, we aimed to discuss the different dimensions of sustainability in a small winemaking region, through a case study analysis. The study helps understand the mechanisms behind the adoption of sustainable measures in Hungary.

The region's cultural identity is strongly linked to the local wine. Even though winemaking makes a smaller contribution to local economies compared to industries in the bigger towns of the area, it does contribute to local identities and improves prospects for the younger generations locally.

The specialisation and separation of grape growing (the farmer) and wine production (industry), which is typical for historical winemaking regions of Europe, is less typical for Hungary. This special local type of production requires the continuous production and preservation of local knowledge of winemaking among farmers, making it possible for the producers to run businesses where everything from viticulture to winemaking is done by the families themselves. All aspects of sustainability appear at the local level, but they are perceived differently by different actors. Neither the inner aspirations toward sustainability nor the external pressures are very strong at this point yet, but local interactions, consumer demand and other external effects such as global trends may result in the sustainable development of this small wine region in the future. Besides a slow and small-scale move towards ecological sustainability, the social and cultural aspects of sustainability become palpable through the transfer of knowledge between the generations of family wineries.

The demands for uniqueness, local identity, and cultural heritage are becoming increasingly important, and it is worth highlighting that these are the main dimensions of cultural sustainability too. An area is only attractive to consumers if it preserves not only its natural but also its cultural characteristics. Protected, untouched, rural and idyllic, small-scale and inexpensive: these are the key concepts that add the additional value to local wine production; moreover making the area attractive (and maintaining it as such) also helps to sell products locally. This common interest tightens the cooperation between economic actors, as the local cultural networks alleviate the vulnerability of family businesses. Therefore, the farmers, as well as other economic actors, can together survive in their businesses and contribute to developing the image of the place, as an important factor for sustainability.

Author Contributions: Conceptualisation, A.C. and B.C.; theoretical background, B.C. and S.K.; statistical data analysis, B.P.; conducting interviews, B.C., S.K., V.K., and A.B.; methodology, A.C. and B.C.; formal analysis, A.C. and B.C.; writing—original draft preparation, A.C., B.C., S.K., V.K., and A.B.; writing — review and editing, A.C., B.C., and S.K.; visualization, B.P.; project administration, V.K.; funding acquisition, A.C. All authors have read and agreed to the published version of the manuscript.

Funding: This research was funded under the project RURALIZATION and has received funding from the European Union's Horizon 2020 research and innovation programme, grant number 817642. The project website at https:/ / ruralization.eu/.

Data Availability Statement: The interviews presented in this study are stored in RDC in the digital repository of the Centre for Social Sciences (Hungarian Academy of Sciences Centre of Excellence, Eötvös Loránd Research Network) that archives the data of research projects conducted at the Centre (https://kdk.tk.hu/en).

Acknowledgments: We are grateful to two anonymous reviewers for their constructive comments and suggestions that helped to shape the paper.

Conflicts of Interest: The authors declare no conflict of interest.

\section{References}

1. Kovach, I. Földek és emberek. Földhasználók és földhasználati módok Magyarországon; Társadalomtudományi KutatóközpontDebreceni Egyetem: Budapest, Hungary; Debrecen, Hungary, 2016; ISBN 9789638302502.

2. Márquez-García, M.; Jacobson, S.K.; Barbosa, O. Wine with a Bouquet of Biodiversity: Assessing Agricultural Adoption of Conservation Practices in Chile. Environ. Conserv. 2019, 46, 34-42. [CrossRef] 
3. Vlahos, G. Farming System Transformation Impacts on Landscape: A Case Study on Quality Wine Production in a Highly Contested Agricultural Landscape. Land 2020, 9, 120. [CrossRef]

4. Brown Weiss, E. Climate Change, Intergenerational Equity, and International Law. Vt. J. Environ. Law 2007, 9, 615-628. [CrossRef]

5. Beekman, V. Sustainable Development and Future Generations. J. Agric. Environ. Ethics 2004, 17, 3-22. [CrossRef]

6. Passmore, J. Man's Responsibility for Nature: Ecological Problems and Western Traditions, 2nd ed.; Duckworth: London, UK, 1980; ISBN 9780715607565.

7. Kivitalo, M.; Kumpulainen, K.; Soini, K. Exploring culture and sustainabilty in rural Finland. In Cultural Sustainability and Regional Development: Theories and Practices of Territorialisation; Dessein, J., Battaglinu, E., Horlings, L., Eds.; Routlege: New York, NY, USA, 2015; ISBN 1317570049.

8. Soini, K.; Birkeland, I. Exploring the Scientific Discourse on Cultural Sustainability. Geoforum 2014, 51, 213-223. [CrossRef]

9. Santini, C.; Cavicchi, A.; Casini, L. Sustainability in the Wine Industry: Key Questions and Research Trendsa. Agric. Food Econ. 2013, 1, 1-14. [CrossRef]

10. Szolnoki, G. A Cross-National Comparison of Sustainability in the Wine Industry. J. Clean. Prod. 2013, 53, 243-251. [CrossRef]

11. Dreby, J.; Jung, G.; Sullivan, R. At the Nexus of Work and Family: Family Farms in Upstate New York. J. Rural Stud. 2017, 49, 151-161. [CrossRef]

12. Chiswell, H.M. From Generation to Generation: Changing Dimensions of Intergenerational Farm Transfer. Sociol. Rural. 2018, 58, 104-125. [CrossRef]

13. Conway, S.F.; McDonagh, J.; Farrell, M.; Kinsella, A. Going against the Grain: Unravelling the Habitus of Older Farmers to Help Facilitate Generational Renewal in Agriculture. Sociol. Rural. 2021. [CrossRef]

14. Nuthall, P.L.; Old, K.M. Farm Owners' Reluctance to Embrace Family Succession and the Implications for Extension: The Case of Family Farms in New Zealand. J. Agric. Educ. Ext. 2017, 23, 39-60. [CrossRef]

15. Korzenszky, A. Extrafamilial Farm Succession: An Adaptive Strategy Contributing to the Renewal of Peasantries in Austria. Can. J. Dev. Stud. Rev. Can. Détudes Dév. 2019, 40, 291-308. [CrossRef]

16. Sutherland, L.-A.; Darnhofer, I. Of Organic Farmers and 'Good Farmers': Changing Habitus in Rural England. J. Rural Stud. 2012, 28, 232-240. [CrossRef]

17. Conway, S.F.; McDonagh, J.; Farrell, M.; Kinsella, A. Till Death Do Us Part: Exploring the Irish Farmer-Farm Relationship in Later Life through the Lens of 'Insideness'. Int. J. Agric. Manag. 2018, 7, 3-15. [CrossRef]

18. Price, L.; Evans, N. From Stress to Distress: Conceptualizing the British Family Farming Patriarchal Way of Life. J. Rural Stud. 2009, 25, 1-11. [CrossRef]

19. Rizzo, L.S.; Smerghetto, F.; Lucia, M.G.; Rizzo, R.G. Sprawl Dynamics in Rural-Urban Territories Highly Suited for Wine Production. Mapping Urban Growth and Changing Territorial Shapes in North-East Italy. Sustainability 2017, 9, 116. [CrossRef]

20. Poulsen, C.; Mønsted, M. Identity Markers for Wine Producers: Terroir and Beyond. J. Wine Res. 2020, 31, 194-217. [CrossRef]

21. Myles, C.C.; Filan, T.R. Making (a) Place: Wine, Society and Environment in California's Sierra Nevada Foothills. Reg. Stud. Reg. Sci. 2019, 6, 157-167. [CrossRef]

22. Chaminade, C.; Randelli, F. The Role of Territorially Embedded Innovation Ecosystems Accelerating Sustainability Transformations: A Case Study of the Transformation to Organic Wine Production in Tuscany (Italy). Sustainability 2020, $12,4621$. [CrossRef]

23. Papadopoulos, A. Reclaiming local food production and the local-expert knowledge nexus in two wine-producing areas in Greece. In Naming Food after Places: Food Relocalisation and Knowledge Dynamics in Rural Development; Ashgate: Farnham, UK, 2010; pp. 237-264. ISBN 9780754677185.

24. Schimmenti, E.; Zinnanti, C.; Borsellino, V.; Varia, F. The Sicilian Cooperative System of Wine Production: The Strategic Choices and Performance Analyses of a Case Study. Int. J. Wine Bus. Res. 2020, 32, 391-421.

25. Figueroa, E.B.; Rotarou, E.S. Challenges and Opportunities for the Sustainable Development of the Wine Tourism Sector in Chile. J. Wine Res. 2018, 29, 243-264. [CrossRef]

26. Arru, B.; Furesi, R.; Madau, F.A.; Pulina, P. "Value Portfolio", Value Creation and Multifunctionality: The Case Study of an Italian Wine Agritourism Farm. Aestimum 2019, 163-181. [CrossRef]

27. Filopoulos, S.; Frittella, N. Designing Sustainable and Responsible Wine Tourism Experiences. BIO Web Conf. 2019, 12, 03006. [CrossRef]

28. Ibănescu, B.-C.; Stoleriu, O.M.; Munteanu, A.; Iațu, C. The Impact of Tourism on Sustainable Development of Rural Areas: Evidence from Romania. Sustainability 2018, 10, 3529. [CrossRef]

29. Gleirscher, N. Policy Instruments in Support of Organic Farming in Austria. Int. J. Agric. Resour. Gov. Ecol. 2008, 7, 51-62. [CrossRef]

30. Az Ökológiai Gazdálkodás Szerepe Egyre Nagyobb Az Agráriumban. Available online: https://www.ksh.hu/docs/hun/xftp/ stattukor/okogazd/index.html (accessed on 15 July 2021). 